\title{
Influence of the key account manager in the provisioning management: Evidence from staple companies during the events of COVID-19
}

\section{Luis-Ricardo Flores-Vilcapoma ${ }^{a}$, Cynthia-Paola Albengrin-Mendoza ${ }^{a}$, Gabriela-Briggite Gomez-Rojas $^{\mathrm{a}}$, Yuri Sánchez-Solis ${ }^{\mathrm{b}}$ and Wagner Vicente-Ramos ${ }^{\mathrm{a}^{*}}$}

\author{
${ }^{a}$ Universidad Continental, Peru \\ ${ }^{b}$ National University of Huancavelica, Peru \\ C H R O N I C L E \\ Article history: \\ Received June 18, 2021 \\ Received in revised format June \\ 282021 \\ Accepted July 72021 \\ Available online \\ July 72021 \\ Keywords: \\ Key account manage \\ Provisioning of materials \\ Purchasing management \\ Storage management \\ Inventory management
}

\begin{abstract}
A B S T R A C T
The purpose of this research was to evaluate the degree of influence exercised by the Key Account Manager in the provisioning management in the main companies called Staple in Peru, during the events of COVID-19. The research was of type quantitative, cross-sectional and temporal, with a non-experimental design, using a multiple linear regression model and correlation analysis to determine the impact that exists between the variables. The data belongs to the Industrias San Miguel company, distributed in a weekly period from June 2019 to March 2021, which gives 88 observations. The results allow us to conclude that the Key Account Manager is an important manager of the supply of goods during the crisis caused by COVID19 in staple companies.
\end{abstract}

(C) 2022 Growing Science Ltd. All rights reserved.

\section{Introduction}

Currently humanity is going through one of its most serious health crises, for this reason Uddin et al. (2021) maintains that this scenario has caused volatility in the world stock market because of the appearance of COVID-19 (Baanante \& Aguilar, 2020). Considering what was stated by Barouki et al. (2021) the current crisis caused by COVID-19 has been directly influencing commercial activities and their working conditions around the world, due to the lack of contact and physical displacement between their workers, customers and suppliers, which has been bringing a negative effect that will last through the years (Cestau, 2021). This lack of contact referred by Quiroz et al. (2020) is caused by this highly contagious disease that spreads from person to person or through contaminated materials. That is why Qu et al. (2021) states that many governments indicated that greater control of this disease will depend more on its prevention than on its treatment, consequently, they have been adopting mandatory social isolation measures and thereby trying to isolate the source of infection. Under this adverse economic scenario, a term not very alien to the business world comes to the fore, which is the Key Account Manager (KAM), according to Trelles (2020), it states that companies can reinvent themselves and continue their activities even in times of health crisis by doing use of KAM. From the position of Davies and Ryals (2014), the KAM function is better defined within a company, since it will obtain greater benefits and its results will be reflected in customer satisfaction, thereby generating increased trust. What is specified by the European School of Management and Business (2018) states that the objective of KAM is to ensure the maintenance of long-term relationships between the main clients and the organization in an effective way. Likewise, Cegos (2015) considers that KAM is of vital importance in any * Corresponding author.

E-mail address: wvicente@continental.edu.pe (W. Vicente-Ramos) 
organization, since it is in charge of its development, maintenance and differentiation; is that professional capable of interacting with the main clients of the organization, in order to strengthen their bond with each one, generating a greater degree of loyalty. Finally, Esan (2016) defines the KAM or also called key account director, as the person in charge of serving customers who generate greater profitability in a company and whose function is also to be able to develop strategies for their maintenance and long-term relationship.

Peru is no stranger to this health crisis, therefore the current government declared a State of National Emergency throughout the country, adopting preventive measures through mandatory social isolation, where the government guaranteed the acquisition, production and supply of food, pharmaceutical products and essential items. For Baanante and Aguilar (2020), the measures imposed by the government directly harmed formal and informal companies, resulting in an adverse scenario to stimulate employment and consumption, since the measures adopted restricted most activities with the exception of companies called staple. On the other hand, the Corporate Reputation Business Monitor (2020) in its ranking of the 100 most important companies in Peru, has considered the current problems caused by COVID-19, of which we can find 26 companies denominated staple companies, where only 17 are those that process their raw material for further transformation. These companies, due to the restrictions, have not only had to secure their distribution chain for their finished product, but also had to secure their provisioning chain. For this reason, the present research aims to evaluate the degree of influence that KAM exerts on provisioning management in the main companies called staple in Peru, in times of COVID-19.

\section{Literature Review}

\subsection{Provisioning of Materials}

For Ayala (2016), the meaning of provisioning comes to be the function that every company performs in order to be able to supply itself with all the basic materials that it requires in the production process, for its subsequent transformation and commercialization. Likewise, Aparicio (2013) mentions that procurement becomes the process by which an industry improves its performance and optimizes its resources through a better selection, acquisition and storage of inputs that the manufacturing area requires. On the other hand, Lacalle (2013) specifies that the meaning of provisioning versus the meaning of purchases are totally different terms since, while purchases are only limited to acquiring the requested materials, provisioning has broader functions that are: The forecast of materials, selection and classification of suppliers, acquisition of materials in the precise time and at the lowest cost, establish the times and types of payments to suppliers, knowledge of the inventory stock and its correct storage. From the perspective of López (2014), the implementation of a provisioning system contributes enormously to the achievement of the objectives set for a company, because the materials necessary for manufacturing are obtained of optimum quality, at excellent prices, with a continuous and relevant supply. Obtaining as a result, high quality products at competitive prices and also avoiding economic losses caused by unnecessary delays in manufacturing. Likewise, Flores-Vilcapoma et al. (2021) specify that the supply allows the reduction of production costs, thus being able to make subsequent decisions based on these forecasts in a correct and timely manner. Therefore, as purchasing, warehousing and inventory management improve in companies, their production costs are reduced. Likewise, Escudero $(2014,2019)$ states that, to achieve an optimization of resources in a company and that this finally does not increase the costs of the final product, procurement management must ensure adequate acquisition of materials that will be subject to customer needs, it must have adequate control of the warehouse, having a minimum stock of each product and finally it must have an adequate transport system for the transfer of raw materials and finished products within the expected times. Procurement includes three fundamental aspects which are: purchasing, storage and inventory management.

\subsubsection{Purchase management}

Viveros (2013) defines that purchasing management consists of being able to continuously supply all the necessary goods or services that must be included directly or indirectly within the production line, also emphasizing that said provision must fully comply the previously established deadlines, prices, and quality, since any error in the aforementioned would lead to delays and losses in the production processes. A main objective in this management, leads to a correct and efficient selection of suppliers who must adjust to the specific needs and requirements of the company, so that later together they can strengthen lasting relationships and become strategic partners. Proper purchasing management according to Escudero (2014) is determined by an optimal selection of suppliers, which goes beyond a simple search for the lowest cost of the goods or services required by the company, but also other factors must be considered important such as: quality factors, service factors and economic factors. One aspect to consider in the selection of the supplier is that a long-term relationship should be formed with it, which generates constant profitability in both companies. A deficient selection of suppliers will have a direct impact on the direct or indirect costs of production, the quality of the manufactured product, the customer's preference will not be obtained, consequently, there could be the risk of losing the market.

\subsubsection{Storage}

For Brenes (2015) approach, storage becomes a transversal function of logistics, since specific areas are required throughout the production chain where it can be deposited: raw materials, semi-processed products and lastly, a specific place must be 
assigned for the finished products until their subsequent sale and distribution. Likewise, Faber et al. (2018) considers that storage plays a transcendental role within any company, since a correct implementation within the supply chain will contribute to achieving the objectives proposed in a company. Flamarique (2017), describes various types of storage, where each company, according to its needs, adopts some particular form, it will depend on: the type of legal regime that has its facilities (own or rented), according to its needs (subject premium, semi-finished products, groceries, final products), depending on the type of organization (service, warehouse, logistics, distribution), operational needs, or the type of influence exercised by its facilities (first, second or third level).

\subsubsection{Inventory management}

For Meana (2017) the main objective in inventory management is to be able to identify the total stocks in a company and to achieve this, a count and physical verification of each of these must be carried out, in such a way that it can be contrasted with existing documents. Likewise, an adequate inventory management will lead to knowing the stock, the location, the level of rotation, the prices and in addition to the type of storage can be adapted as the case may be. According to Garrido \& Cejas (2017), an optimal inventory management generates profitability for a company, since the absence of an input will lead to delays in the entire production chain, potentially losing customers and thus their demand could suffer consequences in the future.

\subsection{Key Account Manager}

For Le Bon and Hernan (2015), the KAM becomes the person in charge of complex negotiations, large-scale sales and the alignment of internal and external stakeholders. In turn, Palacio (2010) defines KAM as that professional whose main function is to serve and develop exclusive clients, as well as having the ability to transform the objectives of the company into the needs of its clients. Similarly, Lobato and López (2005) are the professionals responsible for seeking and maintaining the most important client portfolio in a company. In accordance with Millman and Wilson (1995), companies in their type of organization have among their collaborators one who stands out with a highly qualified profile, the so-called KAM; This professional must not only exist in the sales area, but there must also be an exclusive KAM in purchases. Likewise, Missirilian and Calvi (2004) consider that every purchasing area in any type of company should have a KAM, so that in this way it can trade with its main suppliers and also be able to balance negotiations with a sales KAM for part of its suppliers. According to Bullemore (2019), the KAM should include three indicators that are: Retention of suppliers, strengthening of relationships and extra purchases.

\subsubsection{Retention of suppliers}

Smith (2002) affirms that it is to have the ability to preserve existing suppliers in order to turn them into strategic suppliers, thereby avoiding investing in a new amount of time searching for a new one. According to Soriano (1994), the main strategy lies in having the ability to prevent our current suppliers from abandoning us or looking for a reason to start the search for new companies which they can supply, thus harming the company in the continuous supply you need.

\subsubsection{Strengthening relationships}

For Cestau (2021), strengthening relationships is a very profitable strategy for any type of company, an essential key being not to consider all clients equally, as some of them require a differentiated treatment. In the opinion of Miranda et al. (2007), a good policy is based on the implementation of norms oriented towards the provider, such as the creation of an effective system of correct and timely attention to complaints, thereby achieving their loyalty and consequently excellent results. Finally, Pérez et al. (2004), the success of any company will depend on its ability to reduce the costs generated in obtaining new suppliers and to increase its retention. It must have the ability to generate adequate treatment for each of them, recognizing their individuality and thus being able to satisfy their own needs, in order to ensure sustained growth and generate profitability.

\subsubsection{Purchases}

Mercado (2006) defines it as the process of acquiring any type of good or service, which must be within the previously specified quality standards, within a specific place and time, maintaining a competitive price in the market, today today there are specific areas within the companies that handle it. For Galiana (2018), correct purchasing management significantly contributes to the scope of the strategies and objectives set by the organization, it should be noted that no company could survive if it lacked suitable suppliers that contribute to its production chain.

\section{Hypothesis}

In the research, the dependent variable is provisioning of materials, which is made up of the following components: Purchasing Management, Storage Management and Inventory Management, Likewise, the independent variable is the Key 
Account Manager (KAM) which is made up of the following components: Repurchase, Purchases from New Suppliers, and Extra Purchases.

Table 1

Variables, dimensions and indicators

\begin{tabular}{|c|c|c|}
\hline Variable & Dimension & Indicator \\
\hline & Retention of Suppliers & Repurchase (RP) \\
\hline \multirow[t]{2}{*}{ Key Account Manager (KAM) } & Strengthening relationships & Purchases from New Suppliers (PNS) \\
\hline & Purchases & Extra Purchases (EP) \\
\hline \multirow[b]{2}{*}{ Purchasing Management (PM) } & \multirow[b]{2}{*}{ Providers } & Number of local Suppliers (SUPP_LOC) \\
\hline & & Number of foreign suppliers (SUPP_FOR) \\
\hline \multirow{2}{*}{ Storage Management (SM) } & \multirow{2}{*}{ Level of merchandise in warehouse (LMW) } & Stock $(\mathrm{STOCK})$ \\
\hline & & Balance (BAL) \\
\hline \multirow[b]{2}{*}{ Inventory Management (IM) } & \multirow{2}{*}{ Inventories (INV) } & Inventory Rotation $\quad\left(\mathrm{INV}_{-}\right.$ROT $)$ \\
\hline & & Merchandise Value (MV) \\
\hline
\end{tabular}

Source: Own elaboration.

For this, according to Zhen et al. (2019) the estimation method will be that of ordinary least squares, since it is the most common method for estimating, where the unknown parameters of a stochastic relationship are the objectives of the estimation, by minimizing the sum of the squared errors.

$\min \sum e^{2}=\sum_{i=i}^{n}\left(y_{i}-b_{0}^{\prime} x_{i}\right)^{2}$

where:

$e^{2}=$ is the error squared to have only positive errors.

$y_{i}=$ is the series of the observed dependent variable.

$b_{0}^{\prime}=$ is the parameter or estimator of the regression.

$x_{i}=$ is the series of the observed independent variable.

$n=$ is the total number of observations in the series.

$i=$ is each observation of each series.

The formula shown simplifies the main objective of the OLS technique, which is to minimize the sum of the squared errors to obtain unbiased, efficient and consistent estimates.

Having the independent and dependent variables identified, the research raises the following hypotheses:

$\mathbf{H}_{1}$ : Repurchase through KAM has a significant and positive impact on the Purchasing Management of a company supplying essential products.

$\mathbf{H}_{2}$ : Purchases from New Suppliers through KAM have a significant and negative impact on the Purchasing Management of the company Industrias San Miguel.

H3: The extra Purchases through the KAM have a significant and negative impact on the Purchasing Management of the company Industrias San Miguel.

H4: The Repurchase through KAM has a significant and positive impact on the Storage Management of Industrias San Miguel.

H5: Purchases from New Suppliers through KAM have a significant and negative impact on the Storage Management of the company Industrias San Miguel.

H6: The extra purchases through KAM have a significant and negative impact on the Storage Management of the company Industrias San Miguel.

$\mathbf{H}_{7}$ : The Repurchase through the KAM has a significant and positive impact on the Inventory Management of the company Industrias San Miguel.

H8: Purchases from New Suppliers through KAM have a significant and negative impact on the Inventory Management of the company Industrias San Miguel.

H9: Extra Purchases through KAM have a significant and negative impact on the Inventory Management of the Industrias San Miguel company.

\section{Methodology}

\subsection{Types of research}

The present investigation is type quantitative, cross-sectional and temporal, with a non-experimental design. To achieve the proposed objective, the results are aimed at using a multiple linear regression model and correlation analysis to determine the impact that exists between the variables, as well as their meaning. 


\subsection{Population and sample}

The data belongs to the Industrias San Miguel company, which is distributed in a weekly period from June 2019 to March 2021, which gives 88 observations for each study variable, a fact that allows stability and consistency in data, and to get closer to reality. The variables and indicators are summarized in the following table together with the abbreviation used in the model.

\section{Results}

\subsection{Descriptive statistics}

Table 2 shows the most relevant descriptive statistics of the study variables. In the case of the KAM variable, we can see how the range is too far from the mean, and this is evidenced by the coefficient of variation which shows a volatility of $21.36 \%$. The RP variable has a more stable range around the mean, but the standard deviation is so large that the coefficient of variation shows that it is a highly volatile variable with $24.64 \%$. The PNS variable shows a range very far from its mean, and a fairly high coefficient of variation, which allows us to identify that it is one of the most volatile series in the model. On the other hand, the EP variable presents a variation coefficient of $34.29 \%$, which would be the variable with the greatest variability in the model. The variable PM shows a volatility of $41.80 \%$, the variable SM and IM show a variability of $32.41 \%$ and $26.63 \%$ respectively.

Table 2

Descriptive Statistics of the data

\begin{tabular}{ccccc}
\hline Variable & Half & Standard Deviation & Rank & 638429 \\
KAM & 825914.4 & 176417.3 & 614273 & $21.36 \%$ \\
RP & 666845.4 & 164352.9 & 226659 & $64.64 \%$ \\
PNS & 103927 & 66824.31 & 110288 & 141 \\
EP & 55141.56 & 37788.77 & 38.623 & 1872844 \\
PM & 92.375 & 503346.7 & 2510955 \\
SM & 1552833 & 679116.7 & $31.80 \%$ \\
\hline IM & 2549495 & & $26.63 \%$ \\
\hline
\end{tabular}

Source: Own elaboration

On the other hand, Table 3 shows the values of the correlations between all the variables of the study. Among them, we can highlight those that show a strongly positive and strongly negative correlation. The Repurchase variable has a positively strong relationship with Inventory Management, while it has a lower relationship with Purchasing Management, and moderately with Storage Management. On the other hand, the variable Purchases from New Suppliers shows a strongly negative relationship with Purchasing Management, and a moderately negative relationship with Storage Management and Inventory Management. While the variable Purchases Extras also presents a negatively strong correlation with Purchasing Management, and a moderately negative correlation with Storage Management and Inventory Management. In aggregate terms, we could say that the Key Account Manager has a positive impact on PM, SM and IM as can be seen in the table, with a correlation value of $0.14,0.49$ and 0.53 respectively. With this, it can be anticipated that KAM has had a greater influence on Inventory Management.

Table 3

Correlations Matrix

\begin{tabular}{|c|c|c|c|c|c|c|c|}
\hline Variable & KAM & RP & PNS & EP & PM & SM & IM \\
\hline KAM & 1 & & & & & & \\
\hline RP & 0.8182 & 1 & & & & & \\
\hline PNS & 0.4126 & -0.1820 & 1 & & & & \\
\hline $\mathrm{EP}$ & 0.3804 & -0.2077 & 0.9496 & 1 & & & \\
\hline PM & 0.1439 & 0.6666 & -0.8013 & -0.8101 & 1 & & \\
\hline SM & 0.4976 & 0.8709 & -0.5622 & -0.6091 & 0.9013 & 1 & \\
\hline IM & 0.5379 & 0.9022 & -0.4955 & -0.5365 & 0.8531 & 0.9917 & 1 \\
\hline
\end{tabular}

Source: Own elaboration

The trend of the aggregated variables was analyzed to know how they have behaved from June 2019 to March 2020 . As can be seen in Fig. 1, the KAM variable had a significant increase at the end of 2019 and remained correlated with the storage management until the beginning of 2020, but after that, the health crisis of COVID-19 caused and impacted both series in a relevant way, causing a structural break in them. However, the break in the storage management was greater than in KAM, as can be seen in figure 1, while the impact on KAM was less. With this, it can be intuited that it is KAM that has maintained the provisioning in the company due to the fall in storage, a fact that remains at historical minimum levels until this year. 


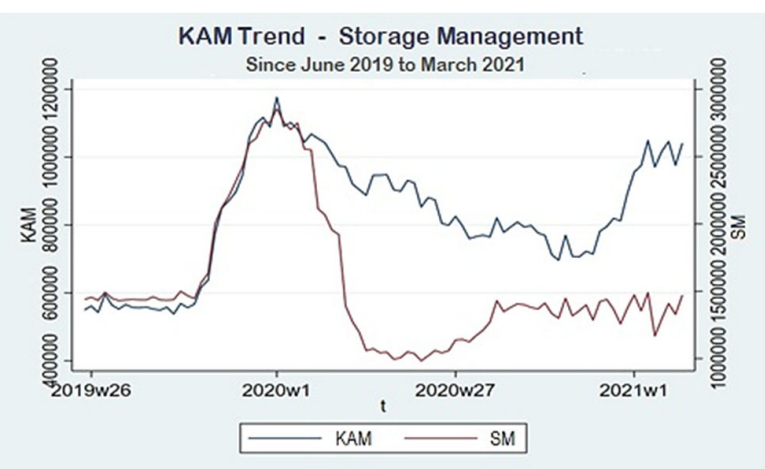

Fig. 1. KAM Trend - SM

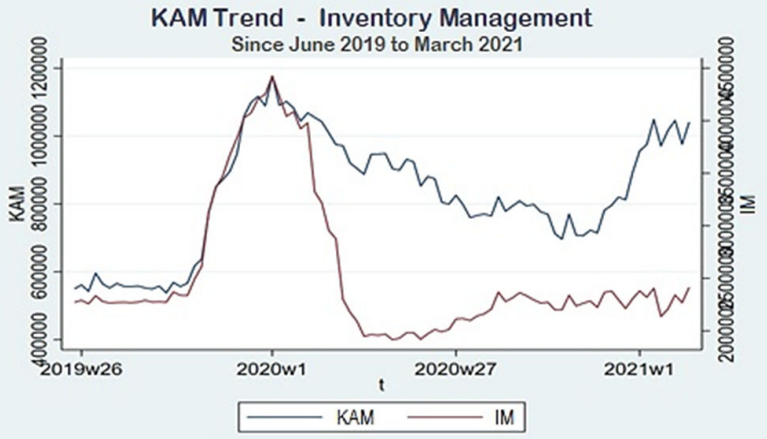

Fig. 2. KAM Trend - IM

Source: Own elaboration

Regarding the trend between KAM and Inventory Management shown in Fig. 2, the impact has been similar as it was with Storage Management, only with small differences. As seen in Table 3 of correlations, Inventory Management and Storage are highly correlated with a value of 0.9917 , almost a perfect correlation, so the differences are small fluctuations at different moments in time, with what should be expected a similar treatment to these two variables in the models. In Fig. 3 we can see the trend of KAM and Purchasing Management, where the latter has had a different behavior than Storage and Inventory Management, and also a higher volatility as seen in Table 2, which has also impacted on a better relationship with the KAM, evidenced with a correlation of 0.14 as seen in table 3. From figure 3, the break in all the structures is clearly visible, but as of the last months of 2020, the variables take an antagonistic behavior, when changing direction from that moment.

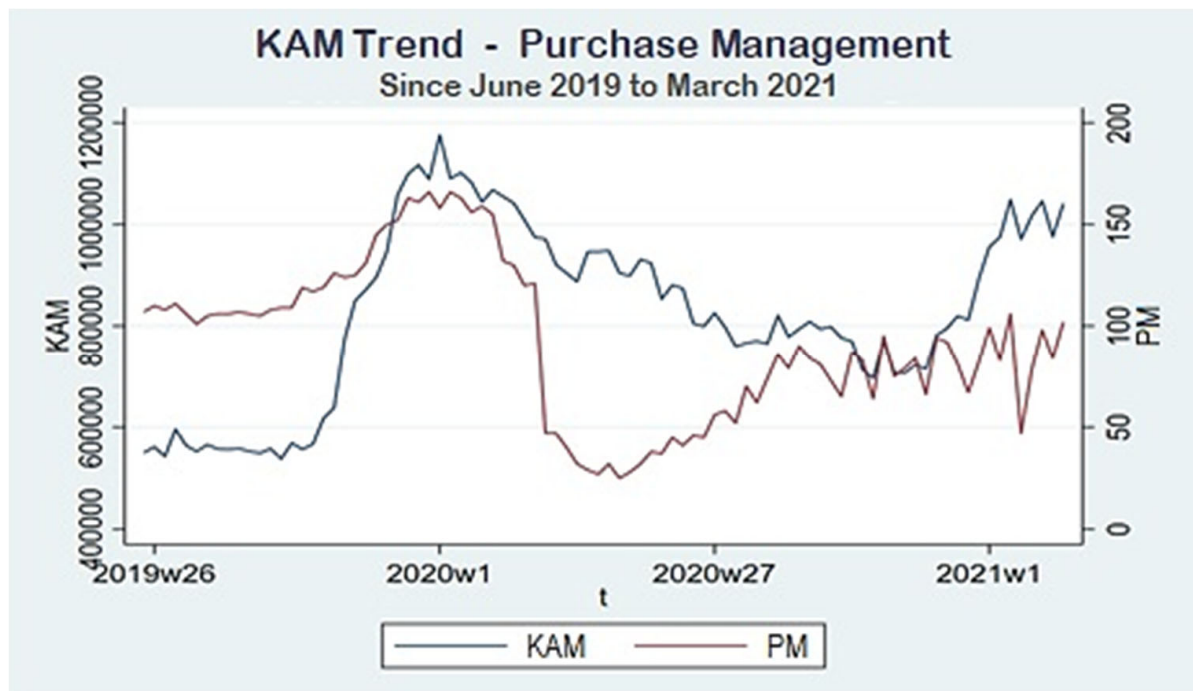

Fig. 3. KAM Trend - PM

Source: Own elaboration

As a result of the figures analyzed, it can be identified that COVID-19 has generated a structural break in all the study series, however, it is the KAM variable that has had a greater resistance to this break, and its fall has not been as notorious as it was for Purchasing, Warehousing and Inventory Management. This fact is supported by the idea that it is this agent who has had a greater relevance in the company, in order to sustain the provisioning in the company.

\subsection{Inferential results}

According to the results shown in the previous section, it was possible to contrast the first hypothesis of the investigation, which indicates that the buyback has a significant and positive impact on the Purchasing Management of the company Industrias San Miguel. Therefore, model 4 of Table 4 shows that this hypothesis should be rejected since the results indicate that the buyback has a negative impact with a coefficient of -0.00 , and this relationship is not significant with a p-value greater than 5\%. Regarding the second hypothesis of the research, which indicates that purchases from new suppliers have a significant and positive impact on the management of purchases of the company San Miguel Industries, before this, model 4 of table 4 shows that said hypothesis It must be accepted since the results show that purchases from new suppliers have a positive impact with a coefficient of 0.001 , and this relationship is significant with a p-value less than $1 \%$. Regarding the third hypothesis of the research, which indicates that the extra purchases have a significant and positive impact on the 
Purchasing Management of the San Miguel company, the results of model 4 of table 4 show that this hypothesis must be accepted Since, these results indicate that extra purchases have a positive impact with a coefficient of 0.001 , and this relationship is significant with a p-value less than $1 \%$. Regarding the fourth hypothesis of the investigation, which indicates that the repurchase has a significant and positive impact on the Storage Management of the San Miguel company, the results of model 4 of Table 5 show that this hypothesis must be accepted, since these results show that the repurchase has a positive impact with a coefficient of 1.91 , and this relationship is significant with a p-value of less than $1 \%$. Regarding the fifth hypothesis, which indicates that purchases from new suppliers have a significant and positive impact on the storage management of the company Industrias San Miguel, the results of model 4 of table 5 show that this hypothesis must be accepted Since these results show that purchasing from new suppliers has a positive impact with a coefficient of 1.06, and this relationship is significant with a p-value of less than 5\%. Regarding the sixth hypothesis of the research, which indicates that the extra purchases have a significant and positive impact on the storage management of the company Industrias San Miguel, the results of model 4 of table 5, show that said hypothesis must be accepted, since these results show that extra purchases have a positive impact with a coefficient of 2.34 , and this relationship is significant with a p-value of less than $1 \%$. Regarding the seventh hypothesis of the research, which indicates that the buyback has a significant and positive impact on the Inventory Management of the San Miguel company, the results of model 1 of table 6 , show that this hypothesis must be accepted, since these results show that the buyback has a positive impact with a coefficient of 3.41, and that said relationship is significant with a p-value of less than 5\%. Regarding the eighth hypothesis of the research, which indicates that purchases from new suppliers have a significant and positive impact on Inventory Management, the results of model 1 of table 6 show that this hypothesis must be rejected, since the results show that purchases from new suppliers have a positive impact with a coefficient of 0.15 , however, the relationship is not significant since the p-value is greater than $1 \%$, $5 \%$ and $10 \%$. Regarding the ninth hypothesis of the research, which indicates that the extra purchases have a significant and positive impact on the Inventory Management of the Industrias San Miguel company, the results of model 1 of table 6 show that said hypothesis must be rejected, since these results show that extra purchases have a negative impact with a coefficient of -6.81 , and this relationship is significant with a p-value of less than $1 \%$.

Table 4

Model Specification for Purchasing Management

\begin{tabular}{|c|c|c|c|c|c|c|c|}
\hline \multicolumn{8}{|c|}{$\begin{array}{c}\text { Method: Ordinary Least Squares } \\
\text { Dependent Variable: Purchasing Management (Levels, Logarithms, Difference and Growth) }\end{array}$} \\
\hline \multicolumn{2}{|r|}{$\begin{array}{l}\text { Model } 1 \\
\text { PM }\end{array}$} & \multicolumn{2}{|c|}{$\begin{array}{c}\text { Model } 2 \\
\text { LOG_PM }\end{array}$} & \multicolumn{2}{|c|}{$\begin{array}{l}\text { Model } 3 \\
\text { DIF PM } \\
\end{array}$} & \multicolumn{2}{|c|}{$\begin{array}{l}\text { Model } 4 \\
\text { V12 PM }\end{array}$} \\
\hline Variable & $\begin{array}{c}\text { Coefficient / } \\
\text { Stand. Dev } \\
\end{array}$ & Variable & $\begin{array}{l}\text { Coefficient / } \\
\text { Stand. Dev }\end{array}$ & Variable & $\begin{array}{l}\text { Coefficient / } \\
\text { Stand. Dev }\end{array}$ & Variable & $\begin{array}{l}\text { Coefficient / } \\
\text { Stand. Dev }\end{array}$ \\
\hline $\mathrm{RP}$ & $0.0001 / 6.84 * * *$ & RP & $1.16 / 1.24 * * *$ & RP & $0.001 / 0.00 * * *$ & DIF_RP & $-0.000 / 0.00$ \\
\hline PNS & $-0.000 / 0.000^{* * *}$ & PNS & $-4.0 / 9.51 * * *$ & PNS & $-0.00 / 0.00$ & DIF_PNS & $-0.001 / 0.00 * * *$ \\
\hline $\mathrm{EP}$ & $-0.0003 / 0.000 * * *$ & EP & $-2.90 / 1.69 * *$ & $\mathrm{EP}$ & $-0.00 / 0.00 * *$ & DIF_EP & $0.001 / 0.000^{* * *}$ \\
\hline $\mathrm{C}$ & $51.90 / 5.27 * * *$ & $\mathrm{C}$ & $4.23 / 0.09 * * *$ & $\mathrm{C}$ & $50.19 / 7.92 * * *$ & $\mathrm{C}$ & $88.76 / 29.65^{* * *}$ \\
\hline $\mathrm{R}^{2}$ & 0.9320 & $\mathrm{R}^{2}$ & 0.8617 & $\mathrm{R}^{2}$ & 0.8533 & $\mathrm{R}^{2}$ & 39.26 \\
\hline Normalcy & 0.5358 & Normalcy & 0.6749 & Normalcy & 0.000 & Normalcy & 0.1209 \\
\hline Het & 0.0347 & Het. & 0.0001 & Het. & 0.000 & Het. & 0.1915 \\
\hline Multi. & 7.19 & Multi. & 7.19 & Multi. & 7.10 & Multi. & 6.43 \\
\hline Autocorr. & 0.0007 & Autocorr. & 0.000 & Autocorr. & 0.0011 & Autocorr. & 0.000 \\
\hline
\end{tabular}

The multivariate result is presented in Table 4, they were the best results from a range of various model tests with different statistical treatments, which resulted in those shown. As can be seen, these models, in turn, evaluate Heteroscedasticity, Autocorrelation, Multicollinearity and Normality of the Residuals. The first model shows all the variables as significant at $1 \%$, a high fit measured by the r-squared, normality in the distribution of the errors, and there is no multicollinearity between the variables of the model, however, it presents an error that does not will allow the coefficients to be interpreted, and this is the fact of presenting heteroscedasticity, with which, the variation of the errors over time is increasing, and it is not zero, as it should be, it also presents serial autocorrelation, which means that the errors of the model are not totally independent of each other, and these explain the present of the errors of the series. On the other hand, models 2 and 3 also present significant coefficients and a high r-squared, however, heterocodasticity is present in the errors of both models, except for Model 4, where the heteroscedasticity problem has been solved in addition to presenting normality in them, and with this, the objective of minimizing the sum of the squared errors, as indicated by the theory, has been achieved. However, the model presents autocorrelation, which, despite being unbiased, will be inefficient as it does not present minimal variance, but this can be attributed to the structural break that occurred in week 12 of 2020 caused by COVID-19. The best model is 4 , since the only error that persists in this model is that of autocorrelation, but the coefficients remain unbiased and consistent. Among the models proposed to explain Storage Management, 4 models were also chosen from which the same problems that they could have due to the presence of structural break were evaluated. Among them, model 4 is the one with the best performance since it presents homoscedastic errors, a high r-square, normality in the errors, there is no multicollinearity between the variables, but it presents autocorrelation. In this model, the logarithms of the storage management were used to smooth the observed break and obtain better results, as well as to differentiate the independent variables, thereby changing their interpretation. In the other models, although the r-squared is greater than that of model 4 , 
the normal distribution of the errors is not fulfilled, nor the homoscedasticity in them, as basic assumptions in this type of statistical technique. On the other hand, all present autocorrelation and none present multicollinearity.

Table 5

Model Specification for Storage Management

\begin{tabular}{|c|c|c|c|c|c|c|c|}
\hline \multicolumn{8}{|c|}{ Method: Ordinary Least Squares } \\
\hline \multicolumn{8}{|c|}{ Dependent Variable: Storage Management (Levels, Logarithm, Difference and Logarithms) } \\
\hline \multicolumn{2}{|r|}{ Model 1} & \multicolumn{2}{|c|}{ Model 2} & \multicolumn{2}{|r|}{ Model 3} & \multicolumn{2}{|c|}{ Model 4} \\
\hline \multicolumn{2}{|r|}{$\mathrm{SM}$} & \multicolumn{2}{|c|}{ LOG_SM } & \multicolumn{2}{|r|}{ DIF_SM } & \multicolumn{2}{|c|}{ LOG_SM } \\
\hline Variable & $\begin{array}{l}\text { Coefficient / } \\
\text { Stand. Dev. }\end{array}$ & Variable & $\begin{array}{l}\text { Coefficient / } \\
\text { Stand. Dev }\end{array}$ & Variable & $\begin{array}{l}\text { Coefficient / } \\
\text { Stand. Dev }\end{array}$ & Variable & $\begin{array}{l}\text { Coefficient / } \\
\text { Stand. Dev. }\end{array}$ \\
\hline RP & $2.38 / 0.076^{* * *}$ & RP & $1.25 / 4.55^{* * * *}$ & DIF RP & $2.40 / 0.07 * * *$ & DIF RP & $1.19 / 5.70 * * *$ \\
\hline PNS & $0.339 / 0.58$ & PNS & $1.37 / 3.49$ & DIF_PNS & $0.040 / 0.58$ & DIF_PNS & $-1.06 / 4.45 * *$ \\
\hline $\mathrm{EP}$ & $-6.53 / 1.04 * * *$ & $\mathrm{EP}$ & $-4.16 / 6021^{* * *}$ & DIF_EP & $-5.93 / 1.05 * * *$ & DIF EP & $-2.34 / 7.96^{* * *}$ \\
\hline $\mathrm{C}$ & $290606.9 / 58854 * * *$ & $\mathrm{C}$ & $13.59 / 0.035 * * *$ & $\overline{\mathrm{C}}$ & $275343.6 / 57934 * * *$ & $\overline{\mathrm{C}}$ & $13.66 / 0.04 * * *$ \\
\hline $\mathrm{R}^{2}$ & 0.9503 & $\mathrm{R}^{2}$ & 0.9452 & $\mathrm{R}^{2}$ & 0.953 & $\mathrm{R}^{2}$ & 0.91 \\
\hline Normalcy & 0.0128 & Normalcy & 0.0007 & Normalcy & 0.0064 & Normalcy & 0.09 \\
\hline Het & 0.0037 & Het. & 0 & Het. & 0.0014 & Het. & 0.3278 \\
\hline Multi. & 7.19 & Multi. & 7.19 & Multi. & 7.58 & Multi. & 7.58 \\
\hline Autocorr. & 0 & Autocorr. & 0 & Autocorr. & 0 & Autocorr. & 0.0332 \\
\hline
\end{tabular}

Table 5 (Continued)

Model Specification for Inventory Management

\begin{tabular}{|c|c|c|c|c|c|c|c|}
\hline \multicolumn{2}{|r|}{ Model 1} & \multirow{2}{*}{\multicolumn{2}{|c|}{$\begin{array}{c}\text { Model } 2 \\
\text { LOG_IM }\end{array}$}} & \multirow{2}{*}{\multicolumn{2}{|c|}{$\begin{array}{l}\text { Model } 3 \\
\text { V12_IM }\end{array}$}} & \multirow{2}{*}{\multicolumn{2}{|c|}{$\begin{array}{l}\text { Model } 4 \\
\text { DIF_IM }\end{array}$}} \\
\hline & & & & & & & \\
\hline Variable & $\begin{array}{l}\text { Coefficient / } \\
\text { Stand. Dev }\end{array}$ & Variable & $\begin{array}{l}\text { Coefficient / } \\
\text { Stand. Dev }\end{array}$ & Variable & $\begin{array}{l}\text { Coefficient / } \\
\text { Stand. Dev }\end{array}$ & Variable & $\begin{array}{l}\text { Coefficient / } \\
\text { Stand. Dev }\end{array}$ \\
\hline $\mathrm{RP}$ & $3.41 / 0.111 * * *$ & $\mathrm{RP}$ & $1.13 / 3.51 * * *$ & $\mathrm{RP}$ & $0.00 / 7.37 * * *$ & $\mathrm{RP}$ & $3.40 / 0.14 * * *$ \\
\hline PNS & $0.15 / 0.85$ & PNS & $2.83 / 2.69$ & PNS & $-0.00 / 0.00 * * *$ & PNS & $2.47 / 1.13 * *$ \\
\hline EP & $-6.81 / 1.52 * * *$ & EP & $-2.51 / 4.78 * * *$ & EP & $0.00 / 0.00$ & EP & $-9.88 / 2.015 * * *$ \\
\hline $\mathrm{C}$ & $633018 / 86281 * * *$ & $\mathrm{C}$ & $14.10 / 0.027 * * *$ & $\mathrm{C}$ & $-51.70 / 6.45^{* * *}$ & $\mathrm{C}$ & $564920 / 115838 * * *$ \\
\hline $\mathrm{R}^{2}$ & 0.9413 & $\mathrm{R}^{2}$ & 0.9497 & $\mathrm{R}^{2}$ & 0.84 & $\mathrm{R}^{2}$ & 0.89 \\
\hline Normalcy & 0.6426 & Normalcy & 0.0707 & Normalcy & 0.1494 & Normalcy & 0.0231 \\
\hline Het & 0.6178 & Het. & 0.0464 & Het. & 0.0021 & Het. & 0.7307 \\
\hline Multi. & 7.19 & Multi. & 7.19 & Multi. & 6.01 & Multi. & 7.1 \\
\hline Autocorr. & 0 & Autocorr. & 0 & Autocorr. & 0 & Autocorr. & 0 \\
\hline
\end{tabular}

Dependent Variable: Inventory Management (Levels, Logarithm, Difference and Logarithms)

Note: *** Significant at $1 \%$, ** Significant at $5 \%$, Significant at $10 \%$

Table 5 shows the best models that explain Inventory Management. Unlike the previous models, in these models it was not necessary to transform the independent variables with logarithms, differences, variations or any other technique, since, by only modifying the dependent variable, many of the problems were solved. In model 1, it can be observed that the r-squared is high, it presents normality in the errors, it does not present heteroscedasticity, therefore, the errors are homoscedastic, there is no multicollinearity in the model, but it presents serial auto-correlation in the model, Despite this, it is presented as the best performing model, since it also presents all the significant variables. In model 2, logarithms were applied to the Inventory Management, with this, the PNS variable is not significant, in addition to heteroskedasticity, abnormality in the errors and auto correlation. In model 3, the variation of Inventory Management was used, that is, its growth, thus achieving normality in errors, but it did not solve the problem of heteroscedasticity nor the self-correlation. While in Model 4 the difference of Inventory Management was used, but this solved the abnormal errors, kept the auto correlation and nonmulticollinearity, however, it made the model Heterocedastic, thereby improving the interpretation. and efficiency of the coefficients.

\section{Discussion and conclusion}

The wide range of statistical results, trends, and causality, allow us to see the true impact relationship that the KAM variable has had on provisioning Management. As initially observed, the data presents a lot of volatility as a consequence of the abrupt changes that occurred as a result of COVID-19 in the internal processes of the company, giving greater relevance to the activity carried out by the KAM, as observed in the trends with Purchase, Storage and Inventory Management. There, it was possible to observe and corroborate that indeed, the Key Account Manager played a very important role in the supply management of the company, since, while the Purchase, storage and inventory management fell, the KAM remained resistant in the activities related to maintain the operation of the company at the normal levels that it should have under normal conditions. 
Therefore, the correlations showed that the KAM played a more important role in Inventory Management and Storage Management, so that they can have the necessary assets for the operations of the company, and to a lesser extent, with the purchasing management. Likewise, the results to a large extent affirm the most relevant theoretical definitions of the literature review, since with what is indicated by the European School of Management and Business (2018) the main direction of KAM is to ensure a long-term relationship between clients and the organization effectively, facts that have been corroborated by the statistical results obtained, since, in the face of the crisis unleashed by COVID-19, the management of inventories, purchases and storage, was strongly weakened and was at that time where the work of the Key Account Manager became more important to preserve the supply of goods, and have a high degree of customer satisfaction, and not go through a stage of internal shortage in the company, a fact that is also linked to what is indicated by Davies and Ryals (2014), and Cegos (2015) who assure that the correct function of the KAM is mainly the development and maintenance of the organization in e 1 provisioning of goods, therefore, in this research case, KAM's functions had a positive impact on many provisioning fields. In summary, the study sought to evaluate the degree of influence exercised by the Key Account Manager in the supply management in the main companies called staple in Peru, in times of COVID-19. The results allow us to conclude that the Key Account Manager has been an important manager of the provisioning of goods during the crisis caused by covid-19 in the company Industrias San Miguel, by safeguarding the supply of intermediate products of the company.

\section{References}

Aparicio, J. M. G. (2013). Gestión logística y comercial. McGraw-Hill/Interamericana de España.

Ayala, J. (2016). Gestión de Compras: Comercio y Marketing. Editorial Editex, Madrid, España.

Baanante, M. J., \& Aguilar, H. N. (2020). El impacto del Covid-19 sobre la economía peruana/The impact of Covid-19 on the Peruvian economy. Economíaunam, 17(51), 136-146. doi.org/10.22201/fe.24488143e.2020.51

Barouki, R., Kogevinas, M., Audouze, K., Belesova, K., Bergman, A., Birnbaum, L., ... \& HERA-COVID-19 working group. (2021). The COVID-19 pandemic and global environmental change: Emerging research needs. Environment international, 146, 106272. doi.org/10.1016/j.envint.2020.106272

Brenes, P. (2015). Técnicas de Almacén: Comercio y Marketing. Editorial Editex, Madrid, España.

Bullemore, J. (2019). Metrics in Key Account Management. https://es.linkedin.com/pulse/las-m\%C3\%A9tricas-en-lagesti\%C3\%B3n-de-cuentas-clave-jorge-bullemore-phd

Cegos. (2015). Key Account Manager, because it is necessary? Cegos Online University. https://www.cegosonlineuniversity.com/por-que-son-necesarios-los-key-account-manager/

Cestau, D. (2021). CRM y fidelización del cliente. Ediciones Deldragón, México.

Pérez, E. M. C., Bernal, M., \& Cuella, L. (2004). El marketing de relaciones: un imperativo en la empresa turística. Gestión de hoteles y restaurantes, $58,30-35$.

Davies, I. A., \& Ryals, L. J. (2014). The effectiveness of key account management practices. Industrial Marketing Management, 43(7), 1182-1194. doi.org/10.1016/j.indmarman.2014.06.007

Decreto Supremo No 044-2020-PCM. Decreto Supremo que declara Estado de Emergencia Nacional por las graves circunstancias que afectan la vida de la Nación a consecuencia del brote del COVID-19. Lima 15 de marzo de 2020. Diario Oficial El Peruano

Esan. (2016). The key account manager and his role in the company's sales. Esan Connection https://www.esan.edu.pe/apuntes-empresariales/2016/07/el-key-account-manager-y-su-papel-en-las-ventas-de-laempresa/

Escudero, M. (2014). Logística de Almacenamiento. Ediciones Paraninfo SA. Madrid, España.

Escudero, M. (2019). Logística de Almacenamiento. Ediciones Paraninfo SA 2da edición del 2019. Madrid, España.

European School of Management and Business. (2018). Key Account Manager: The most requested profile. Eude Business School. https://www.eude.es/blog/key-account-manager/

Faber, N., De Koster, R. B., \& Smidts, A. (2018). Survival of the fittest: the impact of fit between warehouse management structure and warehouse context on warehouse performance. International Journal of Production Research, 56(1-2), 120-139. doi.org/10.1080/00207543.2017.1395489

Flamarique, S. (2017). Gestión de operaciones de almacenaje. Editorial Marge Books, Barcelona, España.

Flores-Vilcapoma, L., Sanchez-Solis, Y., \& Vicente-Ramos, W. (2021). The effect of production costs on the provisioning management of materials: Evidence from paper industry in Peru. Uncertain Supply Chain Management, 9(1), 99-106. doi: $10.5267 /$ j.uscm.2020.11.005.

Galiana, J. (2018). Manual de gestión de compras para logísticos. Editorial Punto Rojo Libros S.L., Valencia, España.

Garrido Bayas, I. Y., \& Cejas Martínez, M. (2017). Inventory Management as a strategic factor in business administration. Revista Negotium, 12(37).

Lacalle, G. (2013). Gestión logística y comercial (Edición 2013). Editex.

Le Bon, J., \& Herman, C. (2015). Key Account Management: Strategies to Leverage Information, Technology, and Relationships to Deliver Value to Large Customers. Business Expert Press.

Lobato Gomez, F., \& López Luengo, M. A. (2005). Gestión de la compraventa. Ediciones Paraninfo, SA.

López Fernández, R. (2014). Logística de aprovisionamiento. Ediciones Paraninfo, SA

Meana, P. (2017). Gestión de inventarios. Ediciones Paraninfo, SA.

Mercado, S. (2006). Compras/Buys: Principios y Aplicaciones/Principles and Applications. Editorial Limusa. 
Business Monitor of Corporate Reputation (2020). Merco Companies Peru $2020 \quad$ Ranking https://www.merco.info/pe/ranking-merco-empresas

Millman, T., \& Wilson, K. (1995). From key account selling to key account management. Journal of Marketing Practice: applied marketing science. doi.org/10.1108/EUM0000000003877

Miranda, F., Chamorro, A., \& Rubio, S. (2007). Introducción a la Gestión de la Calidad.: Delta Publicaciones. Madrid, España.

Missirilian, O., \& Calvi, R. (2004, September). Key Supplier Manager (KSM): an emerging function in purchasing. In 20th IMP Conference, Copenhagen (pp. 2-4).

Palacio, A. M. (2010). Administración de compras: Quien compra bien, vende bien. Ecoe Ediciones

Qu, J. M., Cao, B., \& Chen, R. C. (2021). Prevention and disease control of COVID-19. COVID-19, 75. doi.org/10.1016/B978-0-12-824003-8.00006-1

Quiroz Carrillo, C. G., Pareja Cruz, A., Valencia Ayala, E., Enriquez Valencia, Y. P., De Leon Delgado, J., \& Aguilar Ramirez, P. (2020). Un nuevo coronavirus, una nueva enfermedad: COVID-19. Horizonte Médico (Lima), 20(2). doi.org/10.24265/horizmed.2020.v20n2.11

Smith, J. (2002). Retener y fidelizar a los clientes en una semana. Grupo Planeta (GBS).

Soriano, C. (1994). La Lealtad de Sus Clientes, el activo mas importante de su empresa. Editorial Diaz de Santos S.A., Madrid, España.

Trelles, J. (2020). ¿Y ahora cómo salimos de la crisis? APEM | Escuela Especializada en Marketing y Negocios. https://apem.pe/y-ahora-como-salimos-de-la-crisis/

Uddin, M., Chowdhury, A., Anderson, K., \& Chaudhuri, K. (2021). The effect of COVID-19 pandemic on global stock market volatility: Can economic strength help to manage the uncertainty?. Journal of Business Research, 128, 31-44. doi.org/10.1016/j.jbusres.2021.01.061

Viveros, N. L. H. (2013). Gerencia de compras: La nueva estrategia competitiva. Ecoe Ediciones.

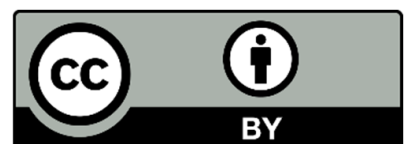

(C) 2022 by the authors; licensee Growing Science, Canada. This is an open access article distributed under the terms and conditions of the Creative Commons Attribution (CC-BY) license (http://creativecommons.org/licenses/by/4.0/). 